\title{
The Equilibrium Analysis of Consumption and Imports of Soybean in Indonesia
}

\author{
Hasdi Aimon ${ }^{*}$, Melti Roza Adry ${ }^{1}$, Zul Azhar ${ }^{1}$ \\ ${ }^{1}$ Faculty of Economics, Universitas Negeri Padang \\ Email:s3dkpl@gmail.com
}

\begin{abstract}
This article aims to explain the influence and equilibrium of soybean price, per capita income and soybean import to soybean consumption in short and long terms in Indonesia. In addition, the effect and equilibrium of real exchange rate, per capita income and soybean consumption to soybean import in short and long-terms in Indonesia are also analysed. The study used time series data from 1986 to 2015, and utilized Co-integration Model and Error Correction Mechanism Model. There are four important findings from the study. First, the soybean price, per capita income and soybean import significantly affected the soybean consumption in Indonesia. Second, in the short-term, the soybean price and per capita income disrupt the equilibrium of soybean consumption, while in the long-term, the consumption of soybeanwill reach back to its equilibrium. Third, the real exchange rate, per capita income, and soybean consumption significantly affected soybean imports in Indonesia. Fourth, the real exchange rate and per capita income disrupts the soybean import in short-term, but it will reach back to its equilibrium in the long-term. Accordingly, it is strongly recommended for the Indonesian government to reduce soybean imports by increasing soybean production and establishing local soybean prices, so that the soybean farmers would feel advantaged.
\end{abstract}

Type of paper: Empirical

Keywords: soybean consumption, soybean import, and soybean price.

\section{Introduction}

The soybean is one of the primary commodities that have an important role in economy of Indonesia due to their high demand as raw materials for various secondary commodities which were commonly found in Indonesia such as soy milk, tempeh, tofu, soy-sauce and soy flour (Meng, Chang, Gillen, \& Zhang, 2016; Preece, Hooshyar, \& Zuidam, 2017; Sanjukta \& Rai, 2016). Soybeans are a vital commodity accepted by most Asian, even in the United States and Canada (Meng et al., 2016; Sanjukta \& Rai, 2016; Xiao-bo, Zhang-xiong, Chun-yan, Wei-guo, \& Li-feng, 2016). 
In 2015, soybean consumption in Indonesia reached 3.05 million tons with an average growth rate of consumption from 1986 to 2015 was around 6.35\%. Meanwhile, the national soybean production in 2015 was only 0.84 million tons with an average growth rate of consumption from 1986 to 2015 was around $2.95 \%$. As a consequence, soybean stock in the input market was inevitably dwindling due to the imbalance between relatively low and stagnant national soybean production and relatively huge and rising soybean consumption.

Therefore, imports of soybeans were an urgent need to cover the deficit between supply and demand of soybean in Indonesia (Zainuri, Wardhono, \& Ridjal, 2015). Based on the data from Central Bureau of Statistic/BPS (2016) (Appendix 1, data were processed by time series analysis), import of soybean in Indonesia tends to rise with an average growth rate of import from 1986 to 2015 was around $16.15 \%$. Similar strategy was also used by The United States of America (Meyers, Devadoss, \& Helmar, 1991) and China (McFarlane \& O’Connor, 2014) when their soybean consumption exceeds their production.

Referring to theory by Blanchard (2011), there is a correlation between consumption and income or output which is available in that country. However, if the domestic production is not enough to fulfill consumption, goods must be imported (Aprianita, Vasiljevic, Bannikova, \& Kasapis, 2014; Chung \& Tan, 2015; Dwiastuti \& Ningsih, 2017; Girik Allo, Sukartini, \& Widodo, 2017).

\section{Literature Review}

This study was based on the theory of consumption and imports theory. According to (Mankiw, 2007), the Keynesian consumption function has three properties (Keynes's conjectures): (i) desire marginal to consume was between zero and one $(0<\mathrm{c}<1)$, (ii) the average tendency to consume would decrease if the income (output) increases, and (iii) consumption was determined by current income (output). However, if this theory is being implied to certain goods (in this case: soybean), then their consumption is determined by their production (output) and income per capita.

Referring to the theory of demand/consumption by Nicholson (Walter, 2005), demand (consumption) may be influenced by the price of the commodity. Hence, based on the theory of macroeconomic and microeconomic theory, consumption may be influenced by commodity prices and output. Considering that the commodities are part of the international trade, consumption is the identity of production (output) and imports (Krugman \& Obstfeld, 2009). Consequently, consumption is not only determined by production, but also determined by import of commodity (Drabik, Gorter, \& Timilsina, 2016). Based on these conditions, consumption function in reduced form was affected by the price and import of the commodity.

According to Blanchard (2011), determinant of domestic imports are subject to domestic income or output and the exchange rate (Amiti, Itskhoki, \& Konings, 2014; Anderson \& Wittwer, 2013; Broz \& Werfel, 2014; Siddig, Aguiar, Grethe, Minor, \& Walmsley, 2014). Since domestic output in international trade was identity as well as in the consumption function, the theory and import function should also be in a reduced form (Miroudot, Sauvage, \& Shepherd, 2013; Tombe, 2015). Consequently, the import function was influenced by the consumption of the commodity, which is correlated with the real exchange rate (rupiah against the US \$). 
Based on theories about consumption and import of commodities, consumption and import of soybean in Indonesia were studied by checking their implication in the form of the influence of exogenous variables to endogenous variables and the balance of short-term and long-term of both the endogenous variables.

Accordingly, the hypothesis of this study can be formulated as followed:

- Soybean prices, income per capita and soybean import might give a significant effect to soybean consumption in Indonesia.

- A balance of short-term and long-term consumption of soybean in Indonesia might exist.

- Exchange rate, per capita income and consumption might give a significant effect on soybean imports in Indonesia.

- There is a balance of short-term and long-term imports of soybean in Indonesia.

\section{Research Methodology}

In this study, research method was designed based on theoretical framework and hypotheses. Accordingly, Keynes consumption model which is the base model in this study can be written as follows:

$$
C=\bar{C}+c Y, \bar{C}>0 \quad 0<c<1
$$

Where $\mathrm{C}$ is soybean consumption, $\mathrm{Y}$ is the production or output of soybeans, is a constant, and $C$ is the marginal desire to consume soybean. Y might be explained in two forms: $\mathrm{Y}$ in the form of production and $\mathrm{Y}$ in the form of income (income per capita) or given the symbol I. Variables income per capita is further development form of Aimon`s model (Aimon, 2014), which only consider Y as a form of production or output. By using this theory, price of soybean can be introduced to consumption model without constant and equation model can be rewritten as followed:

$$
C_{t}=C_{1} Y_{t}+C_{2} I_{t}+C_{3} P_{t}+\mu_{c t}
$$

Where $\mathrm{C}_{\mathrm{t}}$ is soybean consumption, $\mathrm{Y}_{\mathrm{t}}$ is soybean production in $t$ year, $\mathrm{I}_{\mathrm{t}}$ is income per capita in $t$ year, $\mathrm{P}_{\mathrm{t}}$ is soybean price and $\mu_{\mathrm{ct}}$ is error term for soybean consumption models.

Since national soybean production is not able to fulfil the soybean consumption of people in Indonesia, prediction of soybean consumption should include theory of import for a more comprehensive study. In this study, import model also employed a further development form of Aimon's model (Aimon, 2014) which was not considered per capita income as an exogenous variables. Therefore, mathematical models of soybean import in this study can be written as followed:

$$
M_{t}=\alpha_{1} Y_{t}+\alpha_{2} I_{t}+\alpha_{3} E_{t}+\mu_{m t}
$$

Where Mt is the soybean imports in year $t$, and Et is the real exchange rate of the rupiah against the US \$. Furthermore, the concept of consumption, production and import of international economics is a form of identity equation where:

$$
C_{t}=Y_{t}+M_{t} \text { atau } Y_{t}=C_{t}-M_{t}
$$


Thus, by introducing the model in equation (2) and (3) above can be modified when substituted into equation (4). The first will be introduced into equation (2) into equation (4) to be;

$$
\begin{aligned}
& C_{t}=c_{1}\left(C_{t}-M_{t}\right)+C_{2} I_{t}+C_{3} P_{t}+\mu_{c t} \\
& \left(1-c_{1}\right) C_{t}=-c_{1} M_{t}+C_{2} I_{t}+C_{3} P_{t}+\mu_{c t} \\
& C_{t}=\frac{c_{1}}{\left(c_{1}-1\right)} M_{t}+\frac{c_{2}}{\left(c_{1}-1\right)} I_{t}+\frac{c_{3}}{\left(c_{1}-1\right)} P_{t}+\frac{1}{\left(c_{1}-1\right)} \mu_{c t} \\
& C_{t}=\lambda_{1} M_{t}+\lambda_{2} I_{t}+\lambda_{3} P_{t}+v_{t}
\end{aligned}
$$

Soybean consumption model to be estimated is the model in equation (5) to see the effect of imports, per capita income and the price of the consumption good to see the effect of soy and as a basic model to look at the balance of short-term and long-term. Furthermore, import models in equation (3) are changed by substituting equation (4) into equation (3), so it becomes;

$$
\begin{aligned}
& M_{t}=\alpha_{1} C_{t}=\alpha_{1} M_{t}+\alpha_{2} I_{t}+\alpha_{3} E_{t}+\mu_{m t} \\
& M_{t}+\alpha_{1} M_{t}=\alpha_{1} C_{t}+\alpha_{2} I_{t}+\alpha_{3} E_{t}+\mu_{m t} \\
& M_{t}=\frac{\alpha_{1}}{\left(1+\alpha_{1}\right)} C_{t}+\frac{\alpha_{2}}{\left(1+\alpha_{1}\right)} I_{t}+\frac{\alpha_{3}}{\left(1+\alpha_{1}\right)} E_{t}+\frac{1}{\left(1+\alpha_{1}\right)} \mu_{m t} \\
& M_{t}=\gamma_{1} C_{t}+\gamma_{2} I_{t}+\gamma_{3} E_{t}+\varepsilon_{t}
\end{aligned}
$$

Equation (6) above is imported models to be estimated to see the effect of soy consumption, per capita income and the real exchange rate on soybean imports in Indonesia, as well as the basic model to look at the balance of short-term and long-term Indonesian soybean imports. Therefore, the data used in this study are time series data (time series) then Stationery test data by using models Aucmented Dicky Fuller, in which research data is stationary in first difference.

Gujarati (2003) states that the co-integration models can be used to look at the feasibility of regression variables are not stationary against the other so that the variables are not stationary research model can still be done. Besides, co-integration can also be used to view the balance or a long-term relationship between exogenous and endogenous variables. To see the long-term equilibrium relationship or consumption and imports of soybean in Indonesia used equations (7) and (8) the following:

$$
\begin{aligned}
& \partial u c_{t}=\lambda u c_{t-1} \\
& \partial u m_{t}=\phi u m_{t-1}
\end{aligned}
$$

Then, to see the balance or short-term relationship consumption and imports of soybean in Indonesia use an error correction mechanism (ECM) models in the form of equation (9) and (10) as follows:

$$
\begin{aligned}
& \Delta C_{t}=\lambda_{1} \Delta M_{t}+\lambda_{2} \Delta I_{t}+\lambda_{3} \Delta P_{t}+\mu_{c t-1}+\mu_{1 t} \\
& \Delta M_{t}=\gamma_{1} \Delta C_{t}+\gamma_{2} \Delta I_{t}+\gamma_{3} \Delta E_{t}+\mu_{m t-1}++\mu_{2 t}
\end{aligned}
$$

(Gujarati, (2003: 824) 


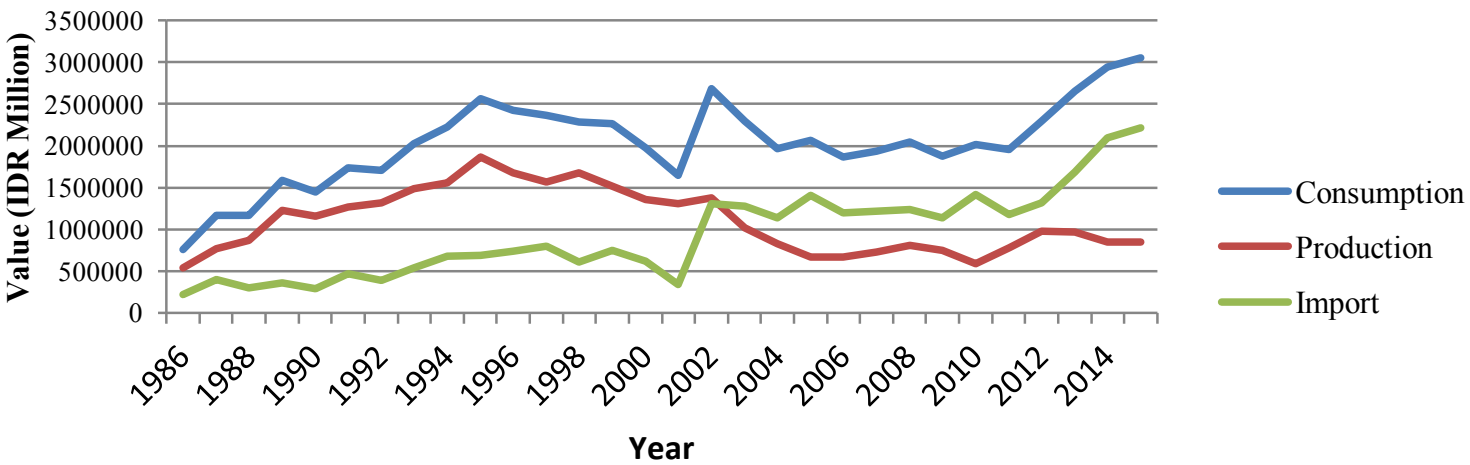

Figure 1. Consumption, production, and import soybean in Indonesia, the period of 1987 to 2015
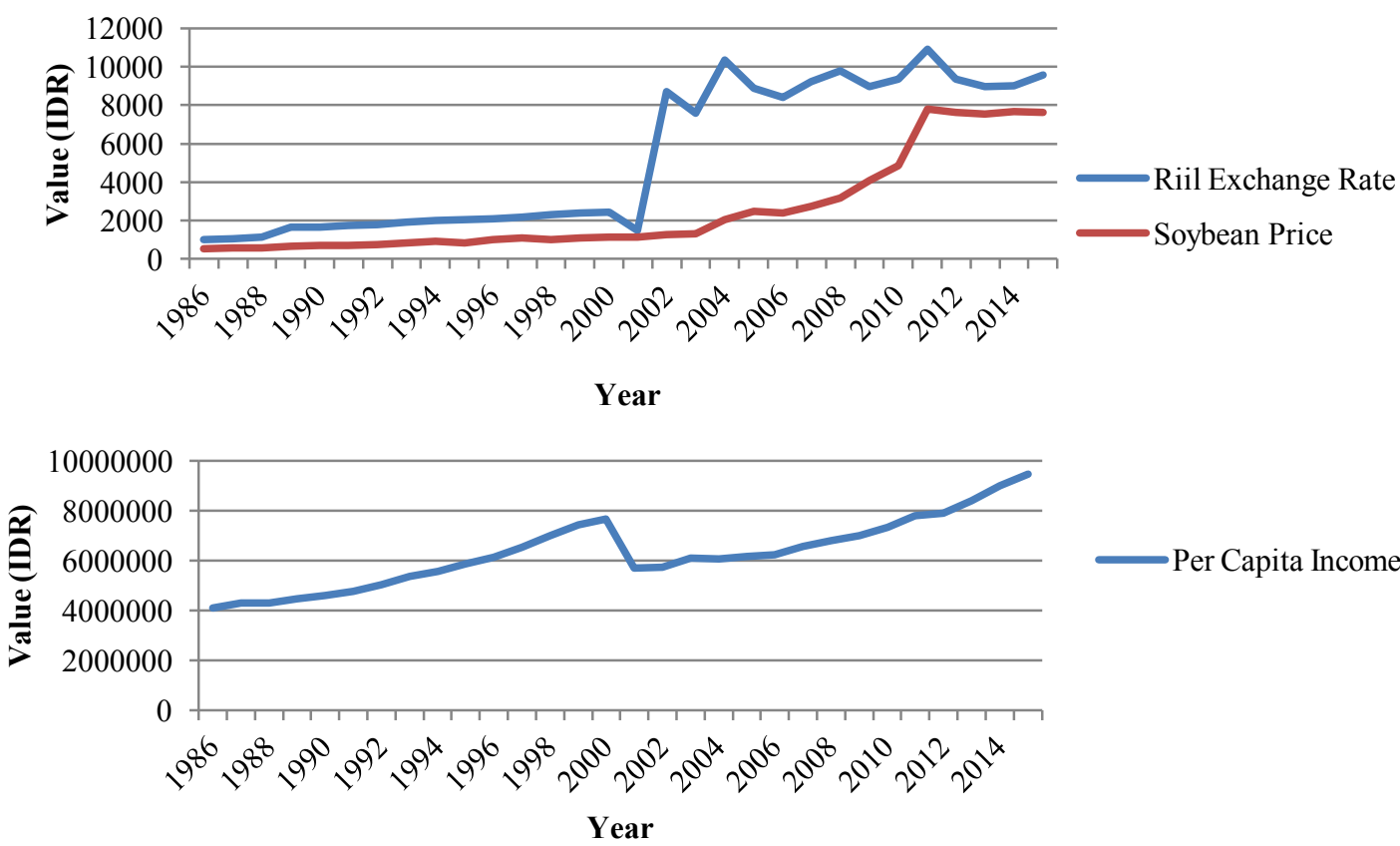

Figure 2. Soybean price, real exchange rate and per capita income in Indonesia, the period of 1987 to 2015

\section{Results and Discussion}

The development of the value of consumption, production, and imports of soybeans from the year of 1987-2016 in Indonesia can be seen in Figure 1. As depicted on Figure 1, soy consumption in Indonesia had an upward trend from 1987 to 1993 . However, it started to decline from the year of 1995 until 2000. Soy consumption trend on the period of 1987 - 1993 was followed by a trend of soybean production.

In the year of 2000, soybean production started to decline and its value was always below 1 million tons. Conversely, consumption kept increasing and caused the increase of imports. In the following year, soybean production kept climbing down and had resulted in the significant increase of imports. This trend follows the trend of the increase in imports of soybean increased 
consumption in Indonesia. In other words, due to the low production of soybean since the year of 2000, the increase in consumption can only be mitigated by increasing imports.

The fluctuating movements in consumption and imports cannot be separated from the variables that affect it. The decrease in consumption of soybean in 2000 occurred due to a sharp rise on the price of soy itself that was executed in order to impose community. This issue was followed by a significant decrease in income per capita of the population and hence, the purchasing power is reduced.

After looking at the development of consumption data, production and import of soybean and its factors - factors that influence it, the following will be the result of data processing with Ordinary Least Square (OLS) to see the effect of exogenous variables on the endogenous variables, Error Correction Mechanism (ECM) to see the balance short-term and Co-integration to see long-term balance between exogenous variables on endogenous variables.

Based on estimate results by Ordinary Least Square (OLS) on Equation 11, it shows that soybean prices, per capita income and soybean imports have a significant effect on the consumption of soy in Indonesia at the alpha level of 1 percent. If the soybean price increases by one unit, the soy consumption decreases by 122.46 . If per capita income increases by one unit, the soybean consumption decreases by 0.2729 and 0.5967 single-unit.

Thus, the results indicate that, in terms of elasticity, the effect of consumption to income per capita soybean and soybean imports is inelastic. An increase in income per capita and soybean imports is greater than an increase in consumption of soy. Therefore, according to the theory, if the Indonesian government can reduce soybean imports, soy consumption will significantly decrease. This is not the case if the domestic soybean production increases, which will be able to increase the consumption of soy.

$$
\mathrm{Ct}=61606.19-122.4628 * * * \mathrm{P}_{\mathrm{t}}+0.272900 * * * \mathrm{I}_{\mathrm{t}}+0.596765 * * * \mathrm{M}_{\mathrm{t}}
$$

Note:

$61606.19=$ constant

$122.4628=$ coefficient estimate

$0.8622=$ probability value

The following discussion is about the short-term relationship between prices, income per capita and the import of soy consumption in Indonesia. So that problems of availability of soy consumption needs are not experiencing the problem for the foreseeable future, these conditions can be seen in the results of the estimation using Error Correction Mechanism model of soy consumption as in Table 2.

The results of model estimation Error Correction Mechanism of soy consumption equation in Equation 12, shows that the error term lag significantly affect change in Indonesian soy consumption. This means that there is an imbalance in the short-term or short-term relationship between price changes and changes in per capita income to changes in the consumption of soy. Changes in soybean prices and per capita income did not significantly affect soybean 
consumption change. It means that the imbalance causes changes in soybean consumption are the two variables namely soybean price changes and changes in per capita income. But in the short-term changes in soybean imports significantly influence changes in Indonesian soy consumption. This condition means that imports in the short-term is still needed because a shortage of consumption in the short-term can still be overcome by the old inventory. However, if left unchecked and not covered by increasing production, imports in the long run cannot be avoided.

$$
\Delta \mathrm{C}_{\mathrm{t}}=\underset{(0.6124)}{26.18053 \Delta \mathrm{P}_{\mathrm{t}}+0.003707 \Delta \mathrm{I}_{\mathrm{t}}+0.915500 * * * \Delta \mathrm{M}_{\mathrm{t}}+0.291467 * * \mathrm{UC}_{\mathrm{t}}-1}
$$

On the other hand, have also seen how the long-term equilbrium or relationship between the two variables. To see the long-term equilibrium of soy consumption can be seen in Equation 13 below:

$$
\begin{gathered}
\Delta U C_{t}=-0.376893^{* * *} U C_{t-1} \\
(0.0091)
\end{gathered}
$$

The estimation results in Table 3 show that the lag error term of soy consumption significantly influences the error term changes in Indonesian soy consumption on alpha 1 percent. It means that the price of soybeans, income per capita and import of soybean and soybean affect consumption will be able to achieve a balance of soy consumption in the long-term. Accordingly, imports of soybeans have become unavoidable in meeting the needs of long-term domestic soybean consumption.

Therefore, even though soy consumption in the short-term was unable to reach the equilibrium, it can be achieved in the long-term. This suggests that it is better for the country to depend more on domestic soybean than imports. Thus, if there is a problem regarding the price of soybeans, income per capita and soybean imports, Indonesia would not be affected.

Furthermore, the results show that the real exchange rate, per capita income and consumption of soy after going through the process of reduced form are among the factors affected the soybean imports in Indonesia. The estimation results using the Ordinary Least Square (OLS) can be seen in Equation 14 of this below.

$$
\mathrm{M}_{\mathrm{t}}=\underset{(0.0004)}{-915879.8+46.21673 * * *} \mathrm{E}_{\mathrm{t}}+\underset{(0.0025)}{0.137995 * *} \mathrm{I}_{\mathrm{t}}+0.350103 * * \mathrm{C}_{\mathrm{t}}
$$

Equation 14 shows that on 5\% significance rate, the real exchange rate, per capita income and consumption of soy positive and significant effect on soybean imports in Indonesia, which means that if real exchange rate went down, the soybean imports will increase by one-unit or 46.21673. Hence, despite the depreciation or appreciation of the exchange rate, soybean imports still increase. This condition shows that soybean imports have zero correlation with the exchange rate against the US \$.

In addition, when the per capita income increased by one-unit, the soybean imports will increase by 0.137995 . The increase in income will increase the purchasing power demand increases. This will encourage imports, if production cannot fulfill the soybean consumption. It is also 
shown by the consumer, that when consumption increases by one-unit, the import will increase by 0.350103 .

The results of the model estimation equation Error Correction Mechanism of soybean imports Equation 15 shows that the lag error term significant effect on the change in Indonesian soy consumption. This means that there is an imbalance in the short-term or short-term relationship between price changes and changes in the real exchange rate to changes in soybean imports. Insignificant changes in soybean prices and the real exchange rate changes have affected changes soy consumption. This means that the imbalance is the cause of change in consumption of soybean price changes and changes in the real exchange rate.

In the short-term, changes in soybean consumption significantly influence changes in soybean imports, which means that changes in consumption does not cause a rise in demand for soybean imports. This is in accordance with the conditions in Table 2 which shows that in the shortterm, the changes do not affect the import of consumption changes in Indonesia. Therefore, the government should pay attention to changes in the price of soybeans and the stability of the exchange rate in order to not cause any disruption on the balance of imports in the short-term.

$$
\Delta \mathrm{M}_{\mathrm{t}}=\underset{(0.4414)}{26995.36-18.36577 \Delta \mathrm{E}_{\mathrm{t}}+\underset{0.2778)}{0.014997 \Delta \mathrm{I}_{\mathrm{t}}+0.524482 * * * \Delta \mathrm{C}_{\mathrm{t}}-0.259011 * *} \mathrm{UM}_{\mathrm{t}-1}}
$$

The long-term balance of soybean imports in Indonesia can be seen in Table 6. It shows that in the long run, soybean imports are able to reach equlibrium. This is shown by the results of the co integration test of changes in soybean imports lagged error term that significantly influence the error term changes in soybean imports $(0.0030<0.01)$. Therefore, the Indonesian government needs to maintain and supervise the import of soybean both in short and long run. When the soybean production cannot fulfill the soybean consumption, the consumer and the producer of soybeans users will blame the government.

$$
\Delta \mathrm{UM}_{\mathrm{t}}=0.528400 * * * \mathrm{UM}_{\mathrm{t}-1}
$$

$$
(0.0030)
$$

The research is identical with Hadi (Yahya, Shaari, \& Huridi, 2011), which used Co-integration and ECM Model between the prices of Crude Palm Oil (CPO) and Crude Oil (COP), and explained the long-term relationship between the prices of CPO and COP. Moreover, the results from the ECM support the presence of dynamic relations between prices of CPO and COP.

\section{Conclusion}

Consumption and imports are inseparable from the economy of Indonesia, since consumption cannot be fully fulfilled by production. Consumption and soybean imports to meet the needs of society are interrelated. Therefore, one thing can lead to repeated problems. The price and income per capita can disrupt the balance of soy consumption in the short-term, while the prices and the real exchange rate can also disrupt the balance of soybean imports in the short-term.

Based on the research findings and co integration test conducted, the equilibrium between soybean consumption and soybean import must be done. Despite some changes and imbalances in the short run, according to the calculation in equation (15), the condition will be stable 
again in the long run. This concept needs to be a serious concern for policy makers and the Indonesian government should handle the imports of soybean carefully so that the balance of soy consumption can be reached, without fully dependent on imports. Furthermore, the government needs to make a pro-active policy in order to stabilize the problem of imbalance of exchange rate, which has created a long-term problems on soybean imports in Indonesia.

There are some limitations of this study. First, the data collected were limited (30 years). Second, since this study not only sees the effect of exogenous variables on the endogenous variables, but also to see if there is a balance of short-term and long-term endogenous variables, it would be better if the study has more data. In this way, the results will be more accurate.

\section{References}

Aimon, H. (2014). Analisis Keseimbangan Konsumsi dan Impor Bahan Bakar Minyak di Indonesia. In Simposium Riset Ekonomi VI 2014 ISEI Surabaya Koordinator Jawa Timur. Surabaya: ISEI Surabaya.

Amiti, M., Itskhoki, O., and Konings, J. (2014). Importers, exporters, and exchange rate disconnect. The American Economic Review, 104(7), 1942-1978.

Anderson, K., \& Wittwer, G. (2013). Modeling global wine markets to 2018: Exchange rates, taste changes, and China's import growth. Journal of Wine Economics, 8(2), 131-158.

Aprianita, A., Vasiljevic, T., Bannikova, A., \& Kasapis, S. (2014). Physicochemical properties of wheat-canna and wheat-konjac composite flours. Journal of Food Science and Technology, 51(9), 1784-1794.

Blanchard, O. (2011). Macroeconomics Fifth Edition. New York: Pearson.

Broz, J. L., \& Werfel, S. H. (2014). Exchange rates and industry demands for trade protection. International Organization, 68(2), 393-416.

Chung, B. H., \& Tan, J. R. (2015). Time series analysis of factors affecting the demand for local rice in Malaysia. International Food Research Journal, 22(5).

Drabik, D., Gorter, H. De, \& Timilsina, G. R. (2016). Producing biodiesel from soybeans in Zambia : An economic analysis. JOURNAL OF FOOD POLICY, 59, 103-109. https:// doi.org/10.1016/j.foodpol.2016.01.001

Dwiastuti, R., \& Ningsih, I. M. (2017). ECONOMIC EFFICIENCY OF SOYBEAN FARMING (CASE STUDY IN MLORAH VILLAGE REJOSO DISTRICT NGANJUK REGENCY). Agricultural Socio-Economics Journal, 16(3), 97-103.

Girik Allo, A., Sukartini, N. M., \& Widodo, T. (2017). Dynamic Changes in Comparative Advantage of Indonesian Agricultural Products. 
Gujarati, D. N. (2003). Basic Econometrics Fourth Edition. Singapore: Tata McGraw-Hill Education.

Krugman, R. P., \& Obstfeld, M. (2009). International Economics: Theory \& Policy. New York: Pearson Addison Wesley.

Mankiw, N. G. (2007). Macroeconomics. New York: Worth Publisher.

McFarlane, I., \& O'Connor, E. (2014). World soybean trade: growth and sustainability. Modern Economy, 5(5), 580-588.

Meng, S., Chang, S., Gillen, A. M., \& Zhang, Y. (2016). Protein and quality analyses of accessions from the USDA soybean germplasm collection for tofu production. Food Chemistry, 213, 31-39. https://doi.org/10.1016/j.foodchem.2016.06.046

Meyers, W. H., Devadoss, S., \& Helmar, M. D. (1991). The World Soybean Trade Model: Specification, Estimation, and Validation.

Miroudot, S., Sauvage, J., \& Shepherd, B. (2013). Measuring the cost of international trade in services. World Trade Review, 12(4), 719-735.

Preece, K. E., Hooshyar, N., \& Zuidam, N. J. (2017). Whole soybean protein extraction processes: A review. Innovative Food Science and Emerging Technologies. https://doi. org/10.1016/j.ifset.2017.07.024

Sanjukta, S., \& Rai, A. K. (2016). Trends in Food Science \& Technology Production of bioactive peptides during soybean fermentation and their potential health bene fi ts. Trends in Food Science \& Technology, 50, 1-10. https://doi.org/10.1016/j.tifs.2016.01.010

Siddig, K., Aguiar, A., Grethe, H., Minor, P., \& Walmsley, T. (2014). Impacts of removing fuel import subsidies in Nigeria on poverty. Energy Policy, 69, 165-178.

Tombe, T. (2015). The missing food problem: Trade, agriculture, and international productivity differences. American Economic Journal: Macroeconomics, 7(3), 226-258.

Walter, N. (2005). Microeconomic theory: basic principles and extensions.

Xiao-bo, W., Zhang-xiong, L. I. U., Chun-yan, Y., Wei-guo, L. U., \& Li-feng, Z. (2016). Stability of growth periods traits for soybean cultivars across multiple locations. Journal of Integrative Agriculture, 15(5), 963-972. https://doi.org/10.1016/S2095-3119(15)61152-2

Yahya, M. H., Shaari, A. H., \& Huridi, M. H. (2011). Investigating Relationship Between Crude Palm Oil And Crude Oil Prices-Cointegration Approach. In 2nd International Conference on Business and Economic Research (2nd ICBER 2011) Proceeding. Conference Master Resources.

Zainuri, A., Wardhono, A., \& Ridjal, J. A. (2015). Competitiveness Improvement Strategy of Soybean Commodity: Study of Food Security in East Java-Indonesia. AGRIS on-Line Papers in Economics and Informatics, 7(3), 99. 